\title{
Rituximab Induced Increased Intraocular Pressure in Recalcitrant Scleritis
}

\author{
Gayatree Mohanty, Shovna Dash
}

Department of Ophthalmology, Kalinga Institute of Medical Sciences \& Pradyumna Bal Memorial Hospital, Bhubaneswar, Odisha, India.

\section{Corresponding Author:}

Dr Shovna Dash

Email: friend.shovna@gmail.com

This is an Open Access article distributed under the terms of the Creative Commons Attribution License (creativecommons.org/ licenses/by/3.0).

Received Accepted

Published

August 26, 2019

December 11, 2019

January 15,2020

\begin{abstract}
Background: We report a rare adverse effect of rituximab, a monoclonal antibody against CD20 antigen targeted lymphocytes, which has been recently used in the potentially sight threatening recalcitrant non-infectious scleritis with promising results. It has been documented to have reduced the need of corticosteroids with minimal adverse effects. Case Report: A 25 year old female with recalcitrant scleritis due to granulomatosis with polyangiitis, not responding to systemic cyclosporine and steroid, presented with increased intraocular pressure following each of the three cycles of rituximab but complete resolution of scleritis. Conclusion: Hence, as the utility of rituximab expands, the awareness of rheumatologists and physicians regarding its ocular adverse effects is crucial.
\end{abstract}

Keywords: Cyclosporine, Intraocular Pressure, Rituximab, Scleritis.

\section{Introduction}

Rituximab, an immunomodulator has been recently used in the potentially vision threatening recalcitrant non-infectious scleritis with promising results. It is a monoclonal antibody against $\mathrm{CD} 20$ antigen targeting B-cell lymphocytes [1]. There have been reports of increased intraocular pressure following intravitreal injection of rituximab for treatment of lymphoma but not due to systemic injection [2]. However, in our case, an abrupt increase in intraocular pressure (IOP) was observed. The purpose of reporting our case is to highlight that rituximab, despite being highly effective in treating scleritis, needs a vigilance for its vision-threatening side-effects and further investigations.

\section{Case Report}

A 25 year old female with recalcitrant scleritis due to granulomatosis with polyangiitis (GPA) was being treated with both topical and systemic corticosteroid along with cyclosporine since 2 years. She was a known case of GPA with joint involvement, positive cytoplasmic anti neutrophil cytoplasmic antibodies (c-ANCA), high $\mathrm{C}$ - reactive protein and high erythrocyte sedimentation rate. Her respiratory and renal profile was normal. She had no signs of glaucoma or steroid induced glaucoma in her past followups. There was no family history of glaucoma. She was recommended rituximab $1000 \mathrm{mg}$ one month apart by the rheumatologist for recalcitrant scleritis. After one day of taking the first dose of rituximab, she presented in our clinic with sudden onset of blurred vision.

On examination, her vision was $6 / 60$ with severe corneal edema in both eyes. The intraocular pressure was $60 \mathrm{mmHg}$ (right eye) and $30 \mathrm{mmHg}$ (left eye) on applanation tonometry. The anterior chamber was deep and there were no signs of inflammation. There was no vitritis. Fundus could not be appreciated because of corneal edema. At the time of this episode she was not on any form of corticosteroids. She was 
not under any other medication which could cause raised IOP. The intraocular pressure was reduced to normal limits with systemic and topical antiglaucoma drugs and she was kept on maintenance with eyedrop dorzolamide and timolol $0.5 \%$ combination twice a day. Her pressure was maintained well and there was no recurrence of scleritis or requirement of any systemic and topical corticosteroids. Fundus was normal. But she presented to our clinic again following her second and third cycle of rituximab, with blurred vision, cloudy cornea, normal anterior chamber and IOP above $30 \mathrm{mmHg}$ requiring systemic acetazolamide despite the maintenance dose of topical dorzolamide and timolol 0.5\% ( $2^{\text {nd }}$ cycle: IOP of OD $32 \mathrm{mmHg}$ and OS 26 $\mathrm{mmHg} ; 3^{\text {rd }}$ cycle: IOP of OD $30 \mathrm{mmHg}$ and OS $28 \mathrm{mmHg}$ ). Fortunately, the optic nerve head was healthy and the retinal nerve fibre layer optical coherence was normal all throughout the follow-ups.

\section{Discussion}

Scleritis is a severe ocular inflammatory condition which can be infectious or non-infectious. It has been associated with malignancy, autoimmune diseases and post-surgical conditions. It is one of the most common ocular presentations of GPA, occurring in $7-11 \%$ of patients, with diffuse anterior scleritis being encountered most often $[3,4]$. However, necrotizing scleritis is the most malignant form, increasing the risk for globe perforation and loss of vision. Examination reveals red, tender eyes, with capillary closure and non-perfusion. It results in infarction and thinning of the sclera. Extension to neighboring structures including the cornea, trabecular meshwork and ciliary body may occur [5].

Rituximab is a chimeric murine/ human monoclonal antibody against the CD20 antigen on human B cells. It results in the depletion of B-cells and B-cell precursors, though long-lived plasma cells and stem cells are not affected.
Rituximab lowers the levels of circulating IgG and IgM antibody as well as their B-cell source for 6 to 12 months or more [6,7]. It is most commonly used in the treatment of non-Hodgkin's lymphoma, multiple myeloma and chronic lymphocytic leukemia. Rituximab has been shown to be non-inferior to cyclophosphamide in the treatment of granulomatosis with polyangiitis (GPA) and it is now FDA- approved for use in GPA $[1,2,8]$. There are cases to support its use in ocular cicatricial pemphigoid, GPA, Sjogren's disease, and Behçet's disease. This drug can be used to treat intraocular lymphoma as well as orbital disease, particularly those mediated by B-cells, such as Graves' disease. There are case reports of its efficacy in treating scleritis, in particular as a manifestation of systemic disease such as rheumatoid arthritis, Sjogrens, and GPA [9,10,11,12]. Eight children (15 eyes) with severe and longstanding juvenile idiopathic arthritis uveitis, who had an inadequate response in controlling uveitis to one or more biologic agents including tumor necrosis factor blockers and abatacept, received rituximab therapy. It was found that rituximab was effective in allowing prednisone reduction in all subjects [13].

In adults with ocular inflammation most treatment protocols include a single course of two $1,000 \mathrm{mg}$ infusions, 2 weeks apart. This generally results in complete peripheral B cell depletion and disease control with time. In cases, when complete response is not achieved or if patient relapses, an additional infusion is given after several months, resulting in disease quiescence [12]. A review report on the safety of rituximab in patients with cancer and rheumatoid arthritis concluded that serious adverse reactions (e.g increased potential for serious infections, Steven- Johnson syndrome, infusion reaction, pulmonary edema, and progressive multifocal leukoencephalopathy) occur only in a small minority of patients but overall rituximab therapy is safe [14]. 
In a clinical study concerning the efficacy of rituximab in 222 patients with lymphoma, nine of them reported ocular side effects, including conjunctivitis, transient corneal edema, burning sensation, transient or permanent loss of visual function with intravitreal rituximab [15]. Increased IOP with granulomatous uveitis has been documented with intravitreal rituximab for primary vitreoretinal lymphoma. It was speculated that rituximab in the anterior chamber bound the malignant cells and activate macrophages and lymphocytes, and through antibody-dependent cellular cytotoxicity muttonfat keratitic precipitates develop as seen in active anterior segment uveitis [2].

In a case of GPA, exacerbation of ocular inflammation associated with secondary raised IOP was seen after systemic RTX therapy [16]. Suhler et al. observed that treatment with rituximab was well tolerated by most of the patients with refractory, non-infectious scleritis. Some of the patients who developed peri-infusional inflammatory exacerbation were managed well with systemic corticosteroids [17]. In a comparative study, 13 patients with GPA-associated scleritis and/or uveitis were treated with cyclophosphamide and rituximab respectively. Remission was seen in all patients but three patients had re-activation of scleritis post-treatment and one patient had flared vasculitis during treatment. The IOP has not been discussed [18]. A case of stage IV, non-Hodgkin's lymphoma (NHL), who was maintained on rituximab for 12 months developed intense, bilateral periocular erythema, moderate edema, gradual blurring of vision and pain with congestion was managed with steroids [19]. Rise in intraocular pressure following intravitreal injection of rituximab for treatment of lymphoma has been reported in earlier literatures, but not after rituximab systemic therapy [2] [Table 1]. In contradictory, our patient had complete resolution of the refractory scleritis but developed rituximab induced glaucoma. She was very compliant with follow-ups and medications and did not develop irreversible optic neuropathy due to raised intraocular pressure.

\section{Conclusion}

The increase in IOP can occur with systemic rituximab like intravitreal injection. The awareness of ocular toxicity profile is crucial to reduce treatment related ocular morbidity.

Table 1: Previous literatures of adverse effects of rituximab.

\begin{tabular}{|l|l|l|l|l|l|l|}
\hline Literature & Indication of RTX & $\begin{array}{l}\text { Systemic RTX } \\
\text { injection }\end{array}$ & $\begin{array}{l}\text { Intravitreal RTX } \\
\text { injection }\end{array}$ & $\begin{array}{l}\text { Systemic Adverse } \\
\text { Effects }\end{array}$ & Ocular Adverse Effects & $\begin{array}{l}\text { Resolution of } \\
\text { Disease }\end{array}$ \\
\hline $\begin{array}{l}\text { Hashida } \text { et al. }[2] \\
\text { Case report }\end{array}$ & $\begin{array}{l}\text { Vitreoretinal } \\
\text { lymphoma }\end{array}$ & - & + & None & $\begin{array}{l}\text { Transient uveitis with } \\
\text { secondary rise in } \\
\text { intraocular pressure }\end{array}$ & Symptoms resolved \\
\hline $\begin{array}{l}\text { Shih } \text { et al. }[16] \\
\text { Case report }\end{array}$ & $\begin{array}{l}\text { Granulomatosis } \\
\text { with polyangiitis }\end{array}$ & + & - & $\begin{array}{l}\text { Exacerbation of ocular } \\
\text { inflammation }\end{array}$ & $\begin{array}{l}\text { Symptoms } \\
\text { worsened }\end{array}$ \\
\hline $\begin{array}{l}\text { Sulher } \text { et al. }[17] \\
\text { RCT })\end{array}$ & $\begin{array}{l}\text { Granulomatosis } \\
\text { with polyangiitis }\end{array}$ & + & - & None & $\begin{array}{l}\text { Exacerbation of ocular } \\
\text { inflammation }\end{array}$ & Disease resolved \\
\hline $\begin{array}{l}\text { Ahmed } \text { et al. }[18] \\
\text { (RCT) }\end{array}$ & $\begin{array}{l}\text { Granulomatosis } \\
\text { with polyangiitis }\end{array}$ & + & - & $\begin{array}{l}\text { Reactivation of scleritis in } \\
3 \text { patients }\end{array}$ & Disease resolved \\
\hline $\begin{array}{l}\text { Maerneli } \text { et al. }[19] \\
\text { Case report }\end{array}$ & $\begin{array}{l}\text { Non-Hodgkin's } \\
\text { lymphoma }\end{array}$ & + & - & None & Conjunctivitis \\
\hline Our patient & $\begin{array}{l}\text { Recalcitrant scleritis } \\
\text { with granulomatosis } \\
\text { with polyangiitis }\end{array}$ & + & - & None & $\begin{array}{l}\text { Raised intraocular pressure } \\
\text { without uvietis } \\
\text { disease }\end{array}$ & $\begin{array}{l}\text { Complete resolution } \\
\text { of disease }\end{array}$ \\
\hline
\end{tabular}


Contributors: MG: manuscript writing, and patient management; SD: reviewing the literature, manuscript editing and patient management. SD will act as a study guarantor. All authors approved the final version of this manuscript and agreed to be responsible for all aspects of the study.

Funding: None; Competing interests: None stated.

\section{References}

1. Beardsley RM, Suhler EB, Rosenbaum JT, Lin P. Pharmacotherapy of scleritis: current paradigms and future directions. Expert Opin Pharmacother. 2013;14(4):411-424.

2. Hashida N, Ohguro N, Nishida K. Efficacy and complications of intravitreal rituximab injection for treating primary vitreoretinal lymphoma. Transl Vis Sci Technol. 2012;1(3):1.

3. Galor A, Thorne JE. Scleritis and peripheral ulcerative keratitis. Rheum Dis Clin North Am. 2007;33:835-854.

4. Bullen CL, Liesegang TJ, McDonald TJ, DeRemee RA. Ocular complications of Wegener's granulomatosis. Ophthalmology. 1983;90:279-290.

5. Jabs DA, Mudun A, Dunn JP, Marsh MJ. Episcleritis and scleritis: clinical features and treatment results. Am J Ophthalmol. 2000;130:469-476.

6. Lim L, Suhler EB, Smith JR. Biologic therapies for inflammatory eye disease. Clin Experiment Ophthalmol. 2006;34:365-374.

7. Treon SP, Anderson KC. The use of rituximab in the treatment of malignant and nonmalignant plasma cell disorders. Semin Oncol. 2000;27:79-85.

8. Stone JH, Merkel PA, Spiera R, Seo P, Langford CA, Hoffman GS, et al. Ritusimab versus cyclophosphamide for ANCA - Associated vasculitis. N Engl J Med. 2010;363:221-232.

9. Tomkins-Netzer O, Taylor SRJ, Lightman S. Can rituximab induce long-term disease remission in patients with intra-ocular non-infectious inflammation? Ophthalmologica. 2013;230:109-115.

10. Taylor SR, Salama AD, Joshi L, Pusey CD, Lightman SL. Rituximab is effective in the treatment of refractory ophthalmic Wegener's granulomatosis. Arthritis Rheum. 2009;60:1540-1547.

11. Cheung CM, Murray PI, Savage CO. Successful treatment of Wegener's granulomatosis associated scleritis with rituximab. Br J Ophthalmol. 2005;89:1542.

12. Onal S, Kazokoglu H, Koc A, Yavuz S. Rituximab for remission induction in a patient with relapsing necrotizing scleritis associated with limited Wegener's granulomatosis. Ocul Immunol Inflamm. 2008;16:230232.

13. Miserocchi E, Modorati G, Berchicci L, Pontikaki I, Meroni P, Gerloni V. Long term treatment with rituximab in severe juvenile idiopathic arthritis associated uveitis. Br J Ophthalmol. 2016;100:782 786.

14. Kimby E. Tolerability and safety of rituximab (MabThera). Cancer Treat Rev. 2005;31:456-473.

15. Foran JM, Rohatiner AZ, Cunningham D, Popescu RA, Solal-Celigny P, Ghielmini M, et al. European phase II study of rituximab (chimeric anti-CD20 monoclonal antibody) for patients with newly diagnosed mantlecell lymphoma and previously treated mantlecell lymphoma, immunocytoma, and small B-cell lymphocytic lymphoma. J Clin Oncol. 2000;18:317324.

16. Shin CB, Wang YC, Lai CC. Ocular and orbital exacerbation after rituximab therapy for granulomatosis with polyangiitis. Canadian Journal of Ophthalmology. 2019;54(5):237-241.

17. Suhler EB, Lim LL, Beardsley RM, Giles TR, Pasadhika S, Lee ST, et al. Rituximab therapy for refractory scleritis: results of a phase I/II doseranging, randomized, clinical trial. Ophthalmology 2014;121:1885-1891.

18. Ahmed A, Foster CS. Cyclophosphamide or rituximab treatment of scleritis and uveitis for patients with granulomatosis with polyangiitis. Ophthalmic Res. 2019;61(1):44-50.

19. Marnelli MA. A case of chronic conjunctivitis following rituximab therapy. Advances in Hematology 2009; Article ID 272495. 